\title{
孤立波による漂流物の衝突力と付加質量 IMPACT FORCE AND ADDED MASS OF DRIFTAGE BY SOLITARY WAVES
}

\author{
涉谷陽 ${ }^{1} \cdot$ 新井信一 ${ }^{2} \cdot$ 高橋敏彦 ${ }^{2} \cdot$ 相原昭洋 ${ }^{3}$ \\ Akira SHIBUYA, Shinichi ARAI, Toshihiko TAKAHASHI and Akihiro AIHARA \\ 1 学生会員 東北工業大学大学院工学研究科 （干982-8577 宮城県仙台市太白区八木山香澄町 35 番 1 号) \\ 2正会員 工博 東北工業大学教授 都市マネジメント学科（同上） \\ ${ }^{3}$ 正会員 工博 東北工業大学助手 都市マネジメント学科 （同上）
}

\begin{abstract}
Houses placed near coasts of plains are exposed to tsunamis which run up onto the ground. In order to reduce tsunami damage, it is one of practical ideas to make the first floor's walls broken and remaining pillars of houses withstood tsunami attack, so that main properties can be protected on the second floor.

The impulses of impact forces by driftage on solitary waves are measured and translated into the added masses of driftage. Although the impulse and added mass varies as the phase of crash changes, the impulse becomes the maximum when crash occurs near the wave crest and, there, added mass coefficient is about 1.0. Then, if crashing velocity of driftage can be estimated somehow, would be given the maximum impales of the impact which must be used as the input force for structural calculations.
\end{abstract}

Key Words: Tsunami, driftage, impact force, added mass

\section{1. はじめに}

本稿執筆中の 2011 年 3 月 11 日， $\mathrm{M}=9.0$ の東北地 方太平洋沖地震が起き, 津波により大きな被害が発 生した。仙台平野でも波高が $10 \mathrm{~m}$ を優に超える津波 となり，誠に残念なことに海岸に住居していた多く の人命と財産が失われた. 沿岸平野部の住宅は津波 の来襲に対して無防備に近いことから, 本研究では, 避難塔などの設置と早期避難による人命保護ととも に，財産も保護し生活を守る術を仙台平野を対象に して検討しつつあった。それは，津波の規模と発生 確率および住宅などの建築コストと被害の程度を組 み合わせて, 費用対効果の面から最適な津波減災を 検討しようとするものである.

この案の基本となる考え方は，遡上してきた津波 によりある程度以上の力が掛ったときには 1 階部分 の壁が壊れて柱だけになり, 主要な津波の力を逃が して 2 階が無事残る建物を可能にしようとするも のである. 主要な財産を 2 階に守り, 被害後の当面 の生活の場を確保することによって，より速やかな 復興が期待できると考えている. 残念ながらその減 災策を構築する前の今回の災害となってしまった。

さて,このような減災の検討のためには, 避難塔・ 住宅などの構造物に及ぼす津波自身と津波の漂流物 による力を明らかにし把握しなければならない。こ こでは，その中の漂流物が柱に与える衝突力につい て明らかにしようとした。
漂流物による衝突力については松冨 ${ }^{1)}$ や池谷ほか 2) などによる先駆的な研究がなされているが，住宅 等構造物の柱のように津波から見て細い柱体に働く 力は改めて調べる必要がある.

衝突力はその時系列のピーク值が調べられること が多いが，住宅等構造物の場合は柱の材料が木材， 鋼，コンクリートなど色々あり，また，その構造上 の弾性も色々とあり得る。そこで本研究では漂流物 の運動量に着目することとした。すなわち，漂流物 が衝突するときに速度が急変して運動量が変化する が，その量は漂流物の形状により定まると期待され る付加質量に大きく依存し，物体の材料や柱の構造 にあまり左右されないと考えられる。そして，その 付加質量が把握できるならば，現実の津波による衝 突時の速度を推定し, 運 動量の変化, すなわち衝突 力の力積を与え, これを衝突時の構造強度計算の入 力とすれば，構造物の耐力の検討が可能になると考 えられる。

衝突現象の基本的な性質を把握するためには，衝 突時の速度や加速度を色々変えて計測したいので， 実験に使用する波として孤立波を使用した。孤立波 に漂流物を乗せれば，衝突する時の波の位相と波高 を変えることにより衝突の流速や加速度がある程度 様々に変化するからである。 


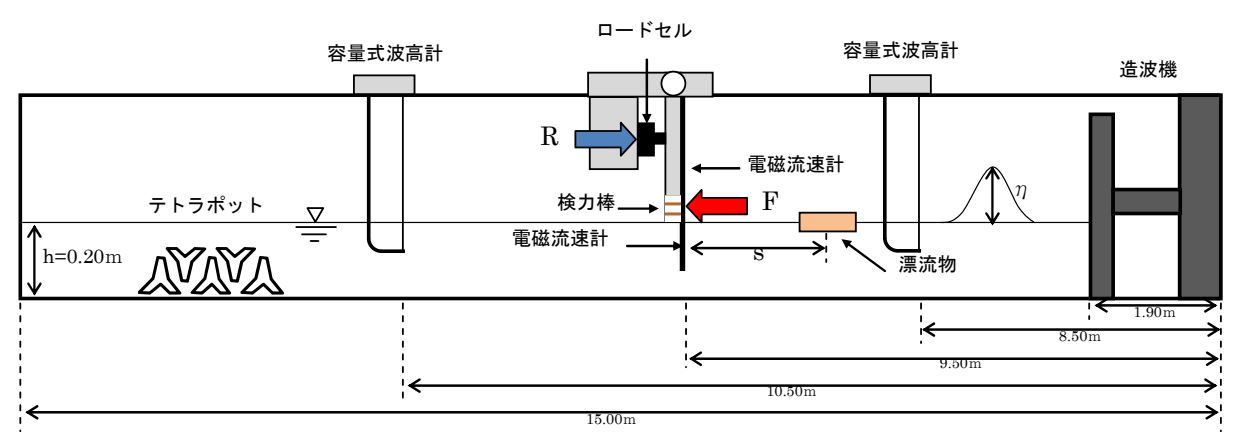

図-1＼cjkstart実験状況（側面図）

従って本研究では, 陸上に遡上した津波を想定せ ず，水深の存在する状態であるけれど孤立波を発生 させ, 衝突力を計測し, その付加質量の性質を明ら かにしようとした。

\section{2. 実験方法}

仙台平野に遡上する津波高さは，今回の震災の結 果, 過小評価となったが，およそ 1 〜 3 と想定した ので，水槽の造波性能上から実験の縮尺は実機のお よそ $1 / 35$ となる。実験状況を図-1 に示す.

あらかじめ漂流物を静水中に浮かべておき孤立波 を発生させると波に乗り，流されて検力棒に衝突す る. 検力棒との距離 $\mathrm{s}$ を色々と変えると衝突すると きの波の位相が変わり, 衝突の速度 $\mathrm{v}$ や加速度 $\alpha$ を 変えることが出来る. 漂流物は孤立波に比べて十分 小さく, 衝突前は水粒子と同じ移動をするので，こ れを求めるために図-2に示すように検力棒（断面寸 法 $2 \mathrm{~cm} \times 0.3 \mathrm{~cm})$ の位置に電磁流速計を配置し流速 を記録した. 衝突力は図-3に示寸検力装置でロード セル（LMA-A 型 小型圧縮型）により反力 $\mathrm{R}$ を計 測し, 後述の方法で作用力 $\mathrm{F}$ を算出した. 検力棒は なるべく薄くし流れを阻害しないようにしている.

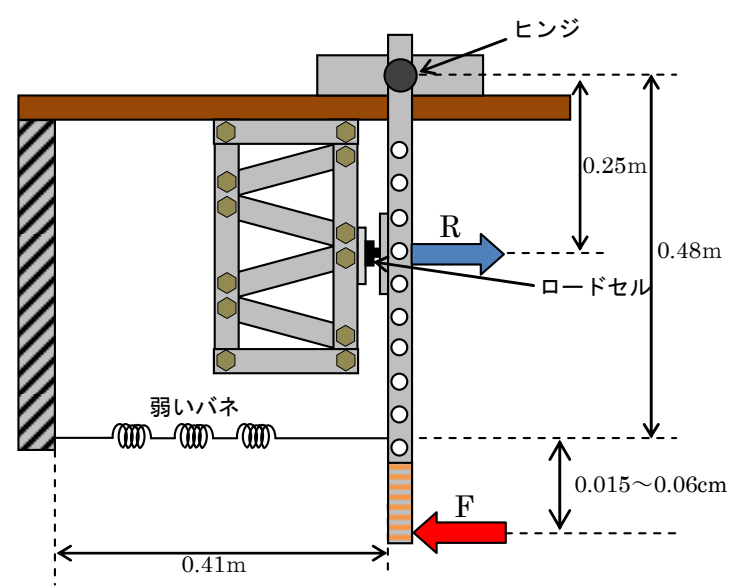

図-3 検力装置

実験に当たり漂流物を孤立波の 9 力所の位相 $\theta$ で 衝突させようとした. それは, 1 つは速度が最大と なる波の頂点でこれを top とし，流速がその $3 / 4$ に

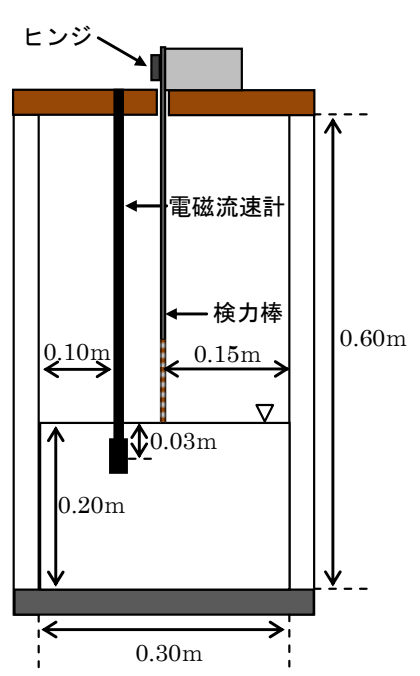

図-2 実験状況（断面図）

なる点で波の前面の点を front $3 / 4$, および後面の点を back3/4 のように命名し, front1/2, front1/4, front0, back1/2, back1/4, back0の合計 9 点である. 図-4に は孤立波の波面上に衝突位相のおよその位置を示し ている，なお，孤立波の波高 $\eta$ は $3 \mathrm{~cm}$ と $5 \mathrm{~cm}$ と $8 \mathrm{~cm}$ で，水深 $\mathrm{h}$ は $20 \mathrm{~cm}$ である.

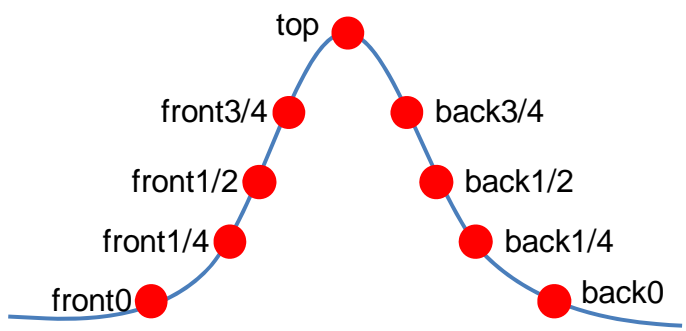

図-4 衝突の位相

漂流物として図-5 に示した（a）厚板型（高さ $3 \mathrm{~cm}$ $\times$ 幅 $5.3 \mathrm{~cm} \times$ 長さ $10 \mathrm{~cm}$ ） と（b）薄板正方形型（高 さ $1.5 \mathrm{~cm} \times$ 幅 $10 \mathrm{~cm} \times$ 長さ $10 \mathrm{~cm}$ ）を使用した。これ は，実機にすると長さ $3.5 \mathrm{~m}$ 程の小型のボートの大 きさとなる，漂流物模型の衝突する方向は，厚板型 が幅直角方向と長さ直角方向の 2 方向であり, 薄板 正方形型が幅と長さが同じなので 1 方向である.

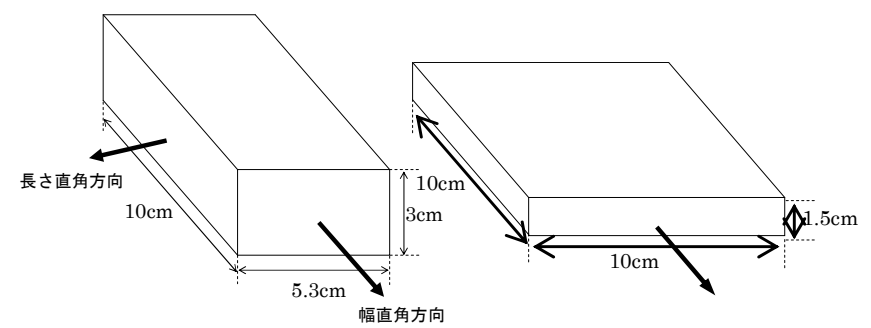

（a）厚板型

（b ）薄板正方形型

図-5 漂流物模型 


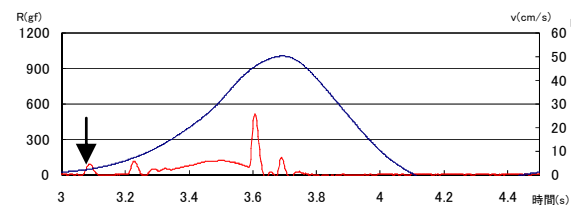

(a) front0

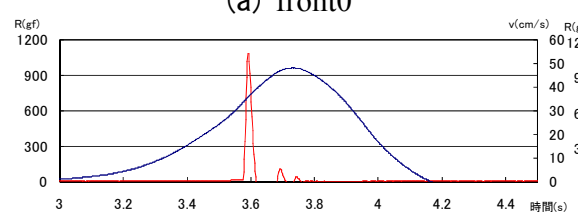

(d) front $3 / 4$

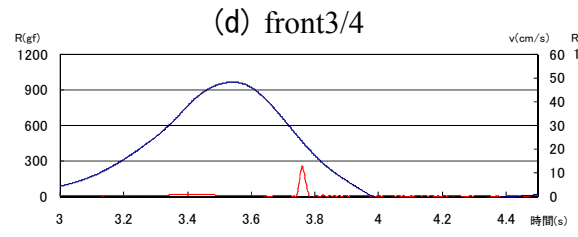

(g) back $1 / 2$

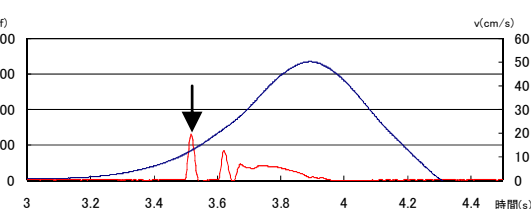

(b) front $1 / 4$

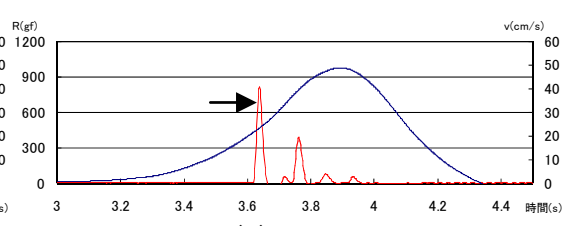

(c) front $1 / 2$

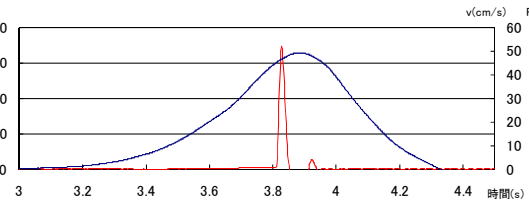

(e) top

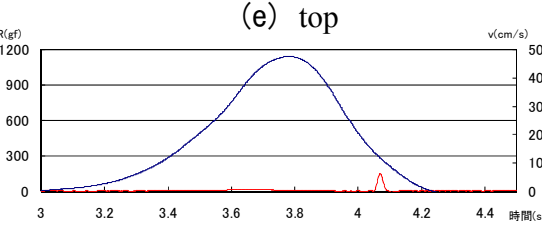

(h) back $1 / 4$

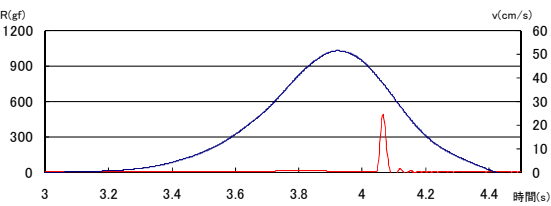

(f) back3/4

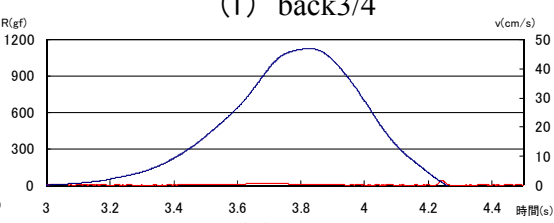

(i) back0

図-6 衝突力，流速の時系列

\section{3. 実験状況と解析方法}

\section{（1）衝突の状況}

図-6には計測された時系列の例を 9 種類の衝突位 相別に示した. 孤立波の波高が $8 \mathrm{~cm}$ の場合で厚板型 の漂流物が幅直角方向で衝突するときの流速 $\mathrm{v}$ と衝 突力 Rである.

front0 から front3/4 までの波の前面では, 漂流物が 複数回衝突していることがわかる。これは, 波の前 面では漂流物が 1 回目の衝突後に検力棒から離れる が，後ろから来る波の部分にすぐ押しつけられて再 び衝突するためである.

top から back0 までの波の頂部から後面において は，漂流物が 1 回の衝突である。波の前面で衝突は 激しく, 後面では弱く小さい. また, 衝突位相ごと に漂流物が検力棒に衝突する角度が異なる。これら の傾向はその他の漂流物や波高における衝突でも同 様である。

参考までに図-7 には front $1 / 2$ のときの衝突した瞬 間と検力棒から離れる瞬間における映像を示した。

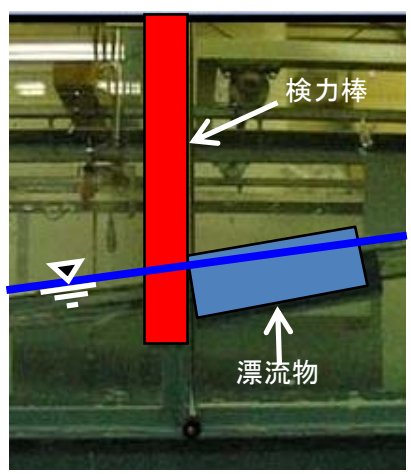

(a) 衝突した瞬間

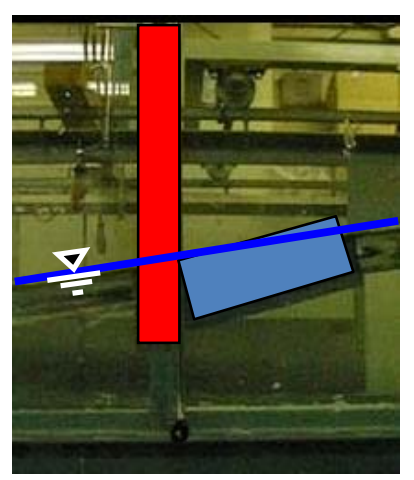

(b) 検力棒から離れる瞬間 図-7 衝突の様子
水面と検力棒と漂流物は認識できるようにスケッ チを加えている．漂流物は，孤立波に乗って衝突す るため水面勾配と同じ傾きで衝突するが，およそ 0.02 秒後の離れる瞬間には水面が変化し, 漂流物の 喫水も変化している様子がわかる.

\section{（2）力積と運動量変化}

衝突力の時系列は図-6 に示したごとくであるが， 複数回の衝突がある場合には力積を求める対象は, 同図に矢印で示すごとく，その第 1 波とした.

まず，力積の求め方を述べる。漂流物による検力 棒への衝撃力 $\mathrm{F}(\mathrm{t})$ は，計測された力 $\mathrm{R}(\mathrm{t})$ (これを以 下では $\mathrm{R}_{\mathrm{M}}(\mathrm{t})$ とする）ではないので， $\mathrm{F}(\mathrm{t})$ を算出する ため検力系を図-8 のように 1 自由度振動計で近似 した.

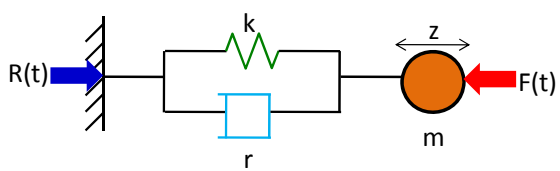

図-8 1 自由度振動モデル

実際の系はもつと複雑となるが，検力棒の剛性を 上げるなどの改良を加え, 後述のように精度のある 近似となっている。

$\mathrm{F}(\mathrm{t})$ が作用する時の振動モデルの運動方程式は (1) 式であり, $\mathrm{m}, \mathrm{r}, \mathrm{k}$ は順に質量, 減衰力係数, 復原 力係数である。

$$
\mathrm{m} \ddot{\mathrm{z}}+\mathrm{rz}+\mathrm{kz}=\mathrm{F}(\mathrm{t}) \cdot ・ ・(1)
$$

外力が時間 $\mathrm{t}$ から始まる単位ステップ入力である と, その応答 $\mathrm{z}_{\mathrm{s}}(\mathrm{t})$ は周知のごとく

$\mathrm{z}_{\mathrm{s}}(\mathrm{t})=\frac{1}{\mathrm{k}}\left[1-\frac{\mathrm{e}^{-\zeta \omega_{\mathrm{n}} \mathrm{t}}}{{\sqrt{1-\zeta^{2}}}^{2}} \cos \left(\sqrt{1-\zeta^{2}} \omega_{\mathrm{n}} \mathrm{t}-\tan ^{-1} \frac{\zeta}{\sqrt{1-\zeta^{2}}}\right)\right] \cdot \boldsymbol{\bullet}(2)$ 
である.ここに, 固有円周波数 $\omega_{\mathrm{n}}=\sqrt{\mathrm{k} / \mathrm{m}}$, 減衰力 係数 $\zeta=\mathrm{r} / 2 \sqrt{\mathrm{m} \mathrm{k}}$ である.

ここで衝突力 $\mathrm{F}(\mathrm{t})$ を図-9 に点線で示すような時刻 $\mathrm{t}$ から始まる高さ $\mathrm{f}_{0}$, 幅 $\Delta \mathrm{t}$ の矩形のインパルスで近 似してみると, その結果の応答 $\mathrm{z}(\mathrm{t})$ は

$$
\mathrm{z}(\mathrm{t})=\mathrm{f}_{0}\left[\mathrm{z}_{\mathrm{s}}(\mathrm{t})-\mathrm{z}_{\mathrm{s}}(\mathrm{t}+\Delta \mathrm{t})\right] \cdots
$$

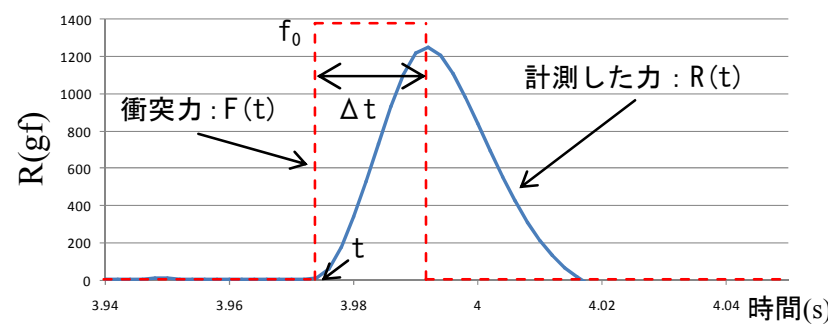

図-9 衝突力， F と R

である。従って，ロードセルに計測される力 $\mathrm{R}$ は解 析的に求められ，これを $\mathrm{R}_{\mathrm{A}}(\mathrm{t})$ とすると，

$$
\mathrm{R}_{\mathrm{A}}(\mathrm{t})=\mathrm{f}_{0} \mathrm{k}\left[\mathrm{z}_{\mathrm{S}}(\mathrm{t})-\mathrm{z}_{\mathrm{S}}(\mathrm{t}+\Delta \mathrm{t})\right] \cdot \cdots(4)
$$

である。この応答值 $\mathrm{R}_{\mathrm{A}}(\mathrm{t})$ は $\omega_{\mathrm{n}}$ と $\zeta, \mathrm{f}_{0}, \mathrm{t}, \Delta \mathrm{t}$ に依 存するので, これらを試行錯誤で調整すると図-9に 示されている計測值 $\mathrm{R}_{\mathrm{M}}(\mathrm{t})$ に近づけることが出来る. 面倒な作業となるが，調整した結果は図-10 に例示 したように良好である。

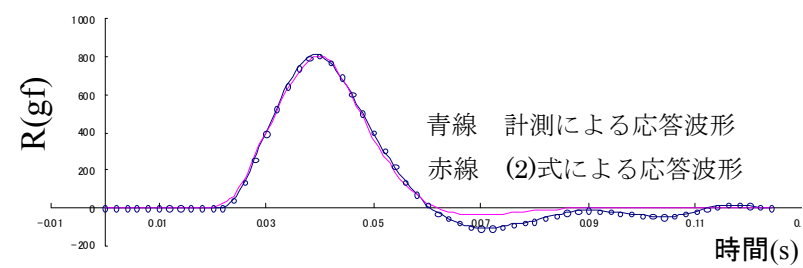

図-10 解析例

さて，前述したように構造設計に必要な衝撃外力 は，運動量の関係を用いて，漂流物の付加質量から 力積を与える方法が良いと考えたので，その付加質 量を調べる. 目視の結果より衝突後の漂流物が停止 するので, 漂流物自身の質量 $\mathrm{m}$ 之流体の付加質量 $\mathrm{m}_{\mathrm{a}}$, 衝突時速度を $\mathrm{v}$ とし, 衝突後の衝突時速度は 0 となり, 力積と運動量変化の関係より (5) 式が得ら れる.よって, この式により付加質量 $\mathrm{m}_{\mathrm{a}}$ が, そして 付加質量係数 $\mathrm{m}_{\mathrm{a}} / \mathrm{m}$ が求められる.

$$
\mathrm{f}_{0} \cdot \Delta \mathrm{t}=\left(\mathrm{m}+\mathrm{m}_{\mathrm{a}}\right) \mathrm{v} \cdot \cdots(5)
$$

なお, 漂流物が孤立波に比べ十分小さいことから， 衝突時速度 $\mathrm{v}$ は先に述べたように, 孤立波の水粒子 速度を漂流物の衝突時速度 $\mathrm{v}$ 計測してそれを使用し た。

\section{4. 実験結果}

\section{(1) 衝突力の力積}

図-11には，漂流物が衝突したときの力積を衝突

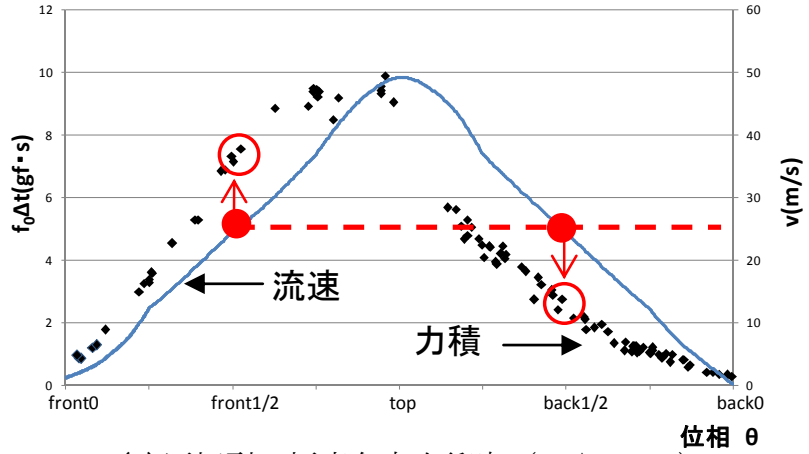

(a) 厚板型，幅直角方向衝突 $(\eta / \mathrm{h}=0.4)$

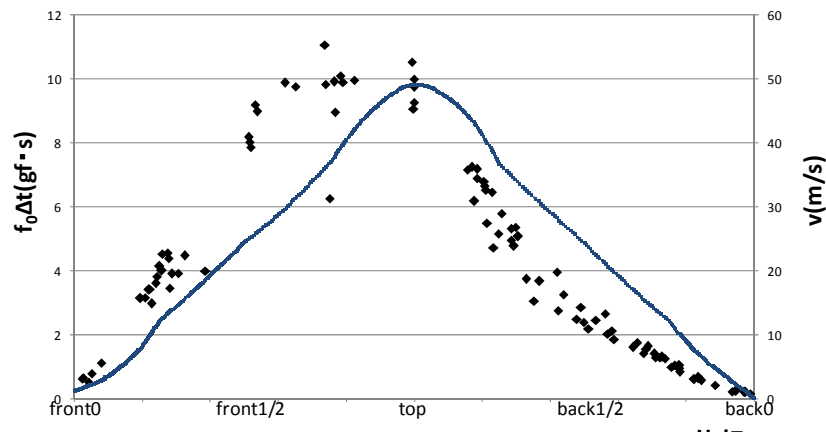

(b) 厚板型，長さ直角方向衝突 $(\eta / \mathrm{h}=0.4)$

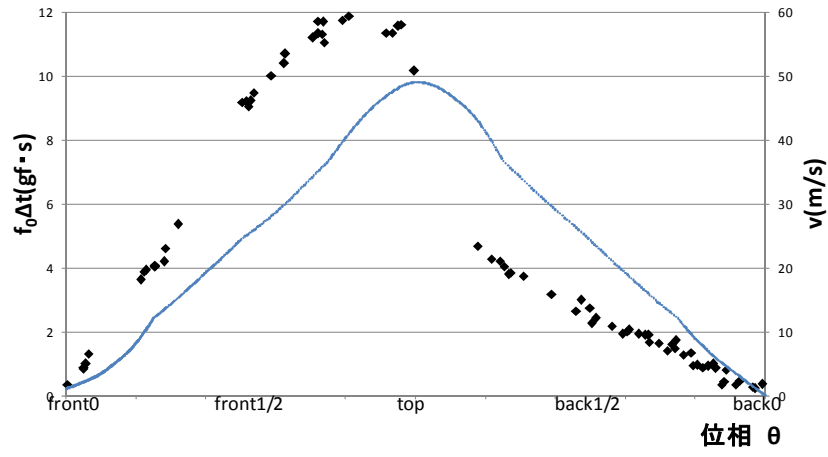

(c) 薄板正方形型衝突 $(\eta / \mathrm{h}=0.4)$

図-11 力積と衝突流速

の位相で整理して示す，漂流物は厚板型（幅直角方 向), 厚板型（長さ直角方向）, 薄板正方形型の場合 であり，孤立波の波高は $8 \mathrm{~cm}$ である.

図中には流速の計測值も実線で示してある。漂流 物はこの速度で衝突する.

力積は front0 から top 付近に掛けて増加し, そこ から back0 に掛けて減少している。しかし，流速は 最大流速点に対してほぼ前後対称形であるのに対し， 力積はそうではない，例えば，図-11(a)では，波の 前面にある赤い点と後面にある赤い点は同じ流速で あるが，力積は前面の方が大きく，後面は小さくな る.

そして,力積の極大值は topから少し前方にくる. ここに示していないが，以上の傾向は孤立波の波高 が変わっても同じである.

図-12 には厚板型漂流物の幅直角方向衝突の力積 につて, 波高が異なる場合の結果を比較している. 波高が大きくなるとほぼそれに比例して力積も大き 
くなることがわかる.この関係は他の漂流物模型で も同様である。

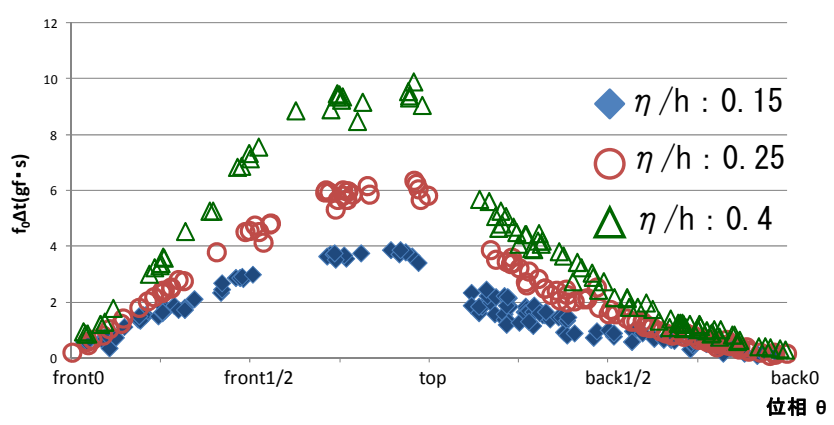

図-12 厚板型, 幅直角方向衝突の力積

\section{（2）衝突時の付加質量}

図-13 は付加質量を漂流物自身の質量で無次元化 した付加質量係数を衝突の位相で整理したものであ る. ここでは図の煩雑化をさけるため, データ点数 の多い所は平均してプロットしている.

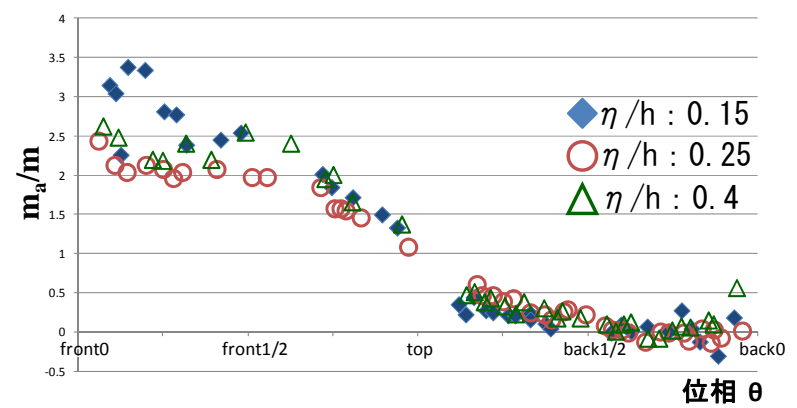

（a）厚板型，幅直角方向衝突

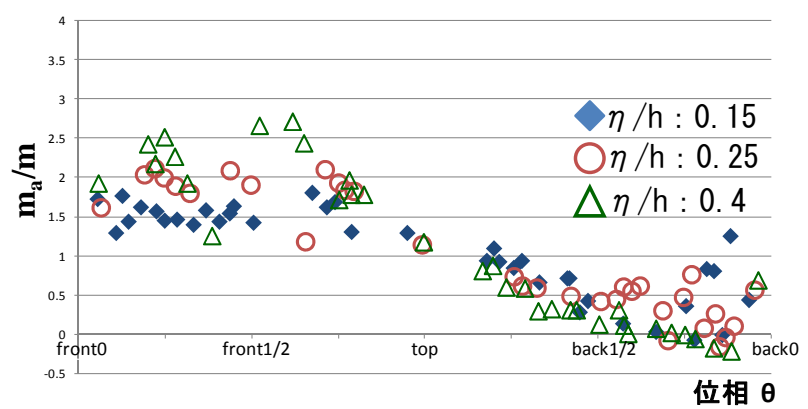

(b) 厚板型，長さ直角方向衝突

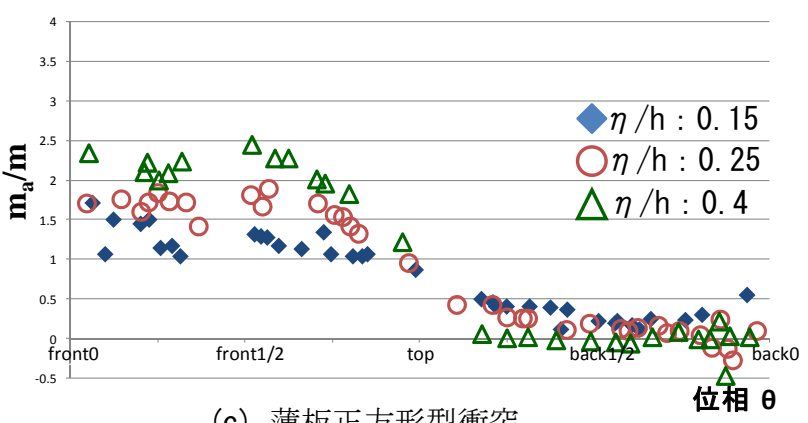

(c) 薄板正方形型衝突

図-13 衝突の位相と付加質量係数
位相の front 0 , back0 付近は結果がばらついている これは，付加質量を計算する際に分母となる流速が ゼロに近い值となるためである。しかし，図-11 と 図-12 にように力積に戻すと top などでの值に比べ て小さい值になるので実用上は無視しても良い。

速度や加速度でこれらのデータを整理すると途中 で結果が折れ曲がるため, 速度や加速度に対して付 加質量が一意に定まらない。しかし，衝突する波の 位相で整理すると図に見るように一意の分布形状を 提示する。

その結果を見ると，まずいずれのケースでも衝突 時の加速度が零となる top では付加質量係数はほぼ 1.0 となる。 そして, 衝突位相が top から前面の front $1 / 2$ に移動すると付加質量係数は増加する.さら に前面に行くと一定值になるように見える.逆に top から後面の back $1 / 2$ にかけて付加質量係数は減少し, それより後面に行くとゼロに収斂していくことが分 かる.

漂流物の運動量で考えているとその速度がぶつか って常に減少するが，流体の場の力を考えると，波 の前面之後面では加速度の方向が変わり, 慣性力の 働く方向も変わることになる．また，図-7に示した ように衝突現象中に喫水が変化するが，その変化の 仕方も前面と後面では逆になる。 その影響が相まっ て先に述べたような付加質量の変化が起きるのでは ないだろうか。

なお, 池野ら ${ }^{3)}$ を見ると, 漂流物の付加質量係数 を約 1.5 (厚板型，幅直角方向）としており，本結果 と比較可能な值を示している.

図-13 (a)の厚板型で長さ直角方向衝突では, 孤立 波波高 $\eta$ にかかわらずほぼ同じ值となってくること が分かる. 前面の位相ではほぼ 2.5 に収斂していく.

図-13 (c) の薄板正方形型では, top から前面への 変化の仕方と後面への変化の仕方が波高毎に違うこ とが見て取れる．すなわち波高が大きいほど変化の 割合が大きくなっている. 前面での付加質量係数の 収斂值は $\eta$ ごとに異なり, $\eta / \mathrm{h}=0.15$ ではほぼ 1.25 , $\eta / \mathrm{h}=0.25$ ではほぼ $1.75, \mathrm{\eta} / \mathrm{h}=0.4$ ではほぼ 2.25 と なり, $\eta$ への依存性が現れる。

図-13 (b) は厚板型の幅直角方向衝突であるが，こ の場合, 漂流物が衝突時に回転をする現象が起きる ため衝突力にばらつきが生じる，その結果ばらつき 具合も大きくなっている。 しかし，よく見ると付加 質量は図-13 (a) と図-13 (c) の中間的変化をしてい ることが読み取れる。

\section{5. まとめ}

孤立波に乗った漂流物の衝突力を計測し，その力 積を解析し, 運動量の式により付加質量に変換して, これらを衝突時の波の位相で整理してみたところ以 下の結果を得た。 
1）衝突力の力積は, 衝突の位相に対応して変化する 速度とともに概ね増加し減少する。それは，孤立 波の前面での衝突では大きくなり, 後面では小さ くなる. 力積の最大值は波 top から少し前面の衝突 時にある。また，力積は波高にほぼ比例して大き くなる。

2）付加質量は加速度がゼロとなる孤立波の top での 衝突時に約 1.0 となる。そして, 前面の衝突では これより大きくなり, 後面の衝突では小さくなる. その増加と減少の仕方は漂流物の形状と衝突の方 向の影響を受ける。

衝突力の特性は当初の予想よりも複雑であった。 しかし, 構造設計上必要な衝突時の力積の最大值は, 波頂の少し前面にあり，その力積の最大值は，付加 質量係数が約 1.0 となる波頂の力積の值の 2 割増し 程度であるから，およその評価は可能である。

今後，陸上遡上の津波による衝突力積を調へ，設
計外力としての衝突力を推定出来るようにしていき たい.

謝辞：本研究の実験とデータ解析にあたり、H20 年 度卒業生の大森涁裕氏、相馬祐介氏、山田誠也氏、 H21 年度卒業生の下田将英氏、本田恭一氏に協力を 頂いた。ここに記して謝意を表す

\section{参考文献}

1) 松冨英夫 : 流木衝突力の実用的な評価式と変化特性, 土木学会論文集, No. 621/II - 47, pp. 111 - 127, 1999

2 ）池谷毅，稲垣聡，朝倉良介，福山貴子，藤井直樹，大 森政則, 武田智吉, 柳沢賢 : 津波による漂流物の衝突 力の実験と評価法の提案, 海岸工学論文集, 第 53 巻, pp. $276-280,2006$

3 ）池野正明, 田中寛好: 陸上遡上津波と漂流物の衝突力 に関する研究, 海岸工学論文集, 第 50 巻, pp. 721 - 725, 2003 